\title{
Highly Efficient Gene Transfer into Adult Ventricular Myocytes by Recombinant Adenovirus
}

Lorrie A. Kirshenbaum, * W. Robb MacLellan, * Wojciech Mazur, * Brent A. French, ${ }^{\star *}$ and Michael D. Schneider ${ }^{\star * 5}$

Molecular Cardiology Unit, Departments of *Medicine, ${ }^{\ddagger}$ Cell Biology, and ${ }^{\S}$ Molecular Physiology

\& Biophysics, Baylor College of Medicine, Houston, Texas 77030

\begin{abstract}
Molecular dissection of mechanisms that govern the differentiated cardiac phenotype has, for cogent technical reasons, largely been undertaken to date in neonatal ventricular myocytes. To circumvent expected limitations of other methods, the present study was initiated to determine whether replicationdeficient adenovirus would enable efficient gene transfer to adult cardiac cells in culture. Adult rat ventricular myocytes were infected, $24 \mathrm{~h}$ after plating, with adenovirus type 5 containing a cytomegalovirus immediate-early promoter-driven lac $Z$ reporter gene and were assayed for the presence of $\beta$-galactosidase $48 \mathrm{~h}$ after infection. The frequency of lac $\mathrm{Z}^{+}$rodshaped myocytes was half-maximal at $4 \times 10^{5}$ plaque-forming units (PFU) and approached $90 \%$ at $1 \times 10^{8}$ PFU. Uninfected cells and cells infected with lac $Z^{-}$virus remained colorless. $\beta$-galactosidase activity concurred with the proportion of lac $Z^{+}$ cells and was contingent on the exogenous lacZ gene. At $10^{8}$ $\mathrm{PFU} /$ dish, cell number, morphology, and viability each were comparable to uninfected cells. Thus, adult ventricular myocytes are amenable to efficient gene transfer with recombinant adenovirus. The relative uniformity for gene transfer by adenovirus should facilitate tests to determine the impact of putative regulators upon the endogenous genes and gene products of virally modified adult ventricular muscle cells. (J. Clin. Invest. 1993. 92:381-387.) Key words: adenovirus $\bullet \beta$-galactosidase • cardiac myocyte $\bullet$ gene transfer $\bullet$ heart
\end{abstract}

\section{Introduction}

The molecular basis for myocardial differentiation and for modulation of the cardiac phenotype by various trophic signals is understood, in large part, through the use of neonatal cardiac myocytes in culture, which are relatively amenable to introduction of plasmids encoding exogenous reporter genes (1-6) and putative regulators $(7,8)$. Developmental regulation of the properties of myocardium is not complete at birth, however, and numerous discrepancies are known between neonatal and adult ventricular muscle cells. Among these are qualitative or quantitative dissimilarities in expression of contractile protein isoforms, the sarcoplasmic reticulum calcium ATPase, atrial

Address correspondence to Dr. Michael D. Schneider, Molecular Cardiology Unit, Baylor College of Medicine, One Baylor Plaza, Room 506C, Houston, TX 77030.

Received for publication 1 December 1992 and in revised form 22 February 1992.

J. Clin. Invest.

(c) The American Society for Clinical Investigation, Inc.

0021-9738/93/07/381/08 \$2.00

Volume 92, July 1993, 381-387 natriuretic factor, transcription factors including c-, $\mathrm{N}-$, and L-myc (9) and the basic-helix-loop-helix protein Id (10), adrenergic receptors (11), G-proteins (12), and endogenous growth factors and their receptors (13) (reviewed in references 13 and 14). Despite the utility of gene transfer into neonatal ventricular myocytes, the extent of these differences has raised concern regarding extrapolation of mechanistic schemes to the adult phenotype itself. Furthermore, even if plasmid-based procedures for gene transfer, using electroporation, DEAEdextran, calcium-phosphate precipitates, or lipofectin, could be implemented for adult ventricular myocytes with success equal to that obtained in neonatal ones, the low efficiency for transient transfection, taken together with the inability to isolate stable transfectants using postmitotic cells, might preclude any effort to modify adult ventricular myocytes with relative uniformity.

Experimental approaches alternative to transfection exist, permitting the analysis of foreign genes within intact adult myocardium. However, direct injection of DNA in situ (15, 16 ) is limited by the meager number of ventricular cells that take up and express injected genes. Conversely, despite its emerging importance for cardiovascular biology (17-20), transgenic technology is limited by the need for specialized equipment, by cost, especially when applied to large mammals, by the lag time between gene injection and the establishment of inbred lines, and by positional effects resulting from variation in the sites of DNA integration, which complicate the systematic comparison of promoter mutations in vivo and necessitate construction and testing of independent pedigrees. Consequently, it would be advantageous to complement these strategies with a means to manipulate the genome of adult ventricular myocytes more uniformly than by direct injection, but retaining the rapid turnaround, unrestricted accessibility to agonists, and freedom from innervation and hormonal effects that are characteristic merits of primary cell culture. To obviate the anticipated limitations of conventional procedures for transfection into terminally differentiated ventricular myocytes, this study was undertaken to determine whether replication-deficient adenovirus can direct efficient gene transfer into adult cardiac myocytes in culture.

\section{Methods}

Isolation of adult ventricular myocytes. Calcium-tolerant adult rat ventricular myocytes were obtained by a modification $(21)$ of the method of Bihler et al. (22). Male Sprague-Dawley rats weighing 250-300 g were injected with sodium heparin $(1,000 \mathrm{U} / \mathrm{kg})$ and killed after $1 \mathrm{~h}$. Hearts were excised and mounted on a modified Langendorff perfusion apparatus which allowed for switching between single-pass and recirculating perfusion at $37^{\circ} \mathrm{C}$. The perfusate consisted of a modified Joklik's calcium-free minimum essential medium, pH 7.4, supplemented with $60 \mathrm{mM}$ taurine, $8 \mathrm{mM}$ glutamic acid, $2 \mathrm{mM}$ DL-carnitine $\mathrm{HCl}, 3.4 \mathrm{mM} \mathrm{MgCl}_{2}, 15 \mathrm{mM}$ glucose, and $0.1 \%$ fatty acid-free bovine 
serum albumin (A-6003; Sigma Chemical Co., St. Louis, MO) (22). After a brief wash-out period, the perfusion system was switched to the recirculating mode for 20 min with Joklik buffer containing $25 \mu \mathrm{m}$ $\mathrm{CaCl}_{2}, 0.1 \%$ albumin, $0.1 \%$ collagenase (CLS2; Worthington Biochemical Corp., Freehold, $\mathrm{NJ}$ ) and $0.1 \%$ hyaluronidase (H3506; Sigma Chemical Co. ). Right and left atrial appendages and extraneous tissues were removed, and hearts were incubated in the same buffer for $20 \mathrm{~min}$ with intermittent shaking. The tissue and cell suspension was gently triturated through pipettes with progressively smaller tip diameters, and filtered through $200-\mu \mathrm{m}$ nylon mesh. The resulting cell suspension was centrifuged three times at $30 \mathrm{~g}$ for $2 \mathrm{~min}$, and resuspended successively in buffer containing $30 \mathrm{mM} \mathrm{KCl}$ and 1,2 , or $4 \%$ albumin. The final cell pellet was resuspended in medium supplemented with $4 \%$ fetal bovine serum. The medium for cell culture consisted of medium 199 (400-1200; GIBCO BRL, Gaithersburg, MD) with Hanks' salts, $1.4 \mathrm{mM} \mathrm{CaCl} 2,0.68 \mathrm{mM}$ glutamine, $1 \mu \mathrm{g} / \mathrm{ml}$ insulin, $5 \mu \mathrm{g} / \mathrm{ml}$ transferrin, $1 \mathrm{nM} \mathrm{LiCl}, 1 \mathrm{nM} \mathrm{Na} \mathrm{SeO}_{4}, 25 \mathrm{ng} / \mathrm{ml}$ ascorbic acid, $1 \mathrm{nM} \mathrm{T}_{3}$, $100 \mathrm{U} / \mathrm{ml}$ penicillin, and $100 \mu \mathrm{g} / \mathrm{ml}$ streptomycin $(1,2,23)$.

Primary cell culture. Adult rat ventricular myocytes were submitted to primary culture by a modification of methods of Piper and colleagues (24). In brief, $35-\mathrm{mm}$ plastic dishes were coated with $20 \mu \mathrm{g} / \mathrm{ml}$ laminin at $37^{\circ} \mathrm{C} 24 \mathrm{~h}$ before cell plating (25). Laminin purified from Engelbreth-Holm Swarm murine tumor cells was kindly provided by T. K. Borg (University of South Carolina, Columbia, SC). Cells were preplated for $2 \mathrm{~h}$ at a density of $1 \times 10^{5}$ cells per dish in medium supplemented with $4 \%$ fetal bovine serum. For the duration of the experimental protocol, the medium then was changed to serum-free medium supplemented with $5 \mathrm{mM}$ carnitine, $5 \mathrm{mM}$ taurine, $5 \mathrm{mM}$ creatine, and $0.2 \%$ bovine serum albumin (24). Cell viability was determined by trypan blue exclusion, scoring at least 250 cells $(n=3$ plates, for each experimental condition). Cell number and morphology were determined by examination of 30 random microscope fields, scoring at least 600 cells $(n=8$ plates, for each experimental condition).

Adenovirus vectors and infection in vitro. The recombinant, replication-deficient adenoviral vectors used in this study were generously provided by Frank L. Graham (McMaster University, Hamilton, Canada). The control virus, AdFG140, was produced by transfection of Ad5-transformed human 293 embryonic kidney cells with pFG140 (26). This bacterial plasmid contains the adenovirus type 5 (Ad5) dl309 genome, harboring mutations in region E3 at 79 and 85 map units, circularly ligated to a plasmid origin of replication and ampicillin resistance gene via the XbaI site at 3.7 map units (27). E1A and E1B sequences, deleted in the recombinant adenoviruses described here, are complemented in trans by propagation of the virus in human 293 cells which host the E1 region, and E3 is not required for viral replication. The $\beta$-galactosidase (lacZ) reporter virus was generated by homologous recombination in 293 cells between plasmid pJM17, a 40.3-kb modification of pFG140 too large to be packaged into adenoviral capsids, and plasmid pHCMVsp1LacZ, which contains the human cytomegalovirus immediate-early promoter, Escherichia coli lacZ gene, and SV40 polyadenylation signal flanked by Ad5 map units $0.0-1.0$ and 9.8-15.8 (A. Bett and F. Graham, personal communication). The resulting recombinant virus, designated AdHCMVsp1 LacZ, integrates the eukaryotic expression cassette into the E1 region, in lieu of E1 A and E1B sequences between 1.0 and 9.8 map units.

The firefly luciferase reporter virus was generated by homologous recombination in 293 cells between the plasmids JM17 and pXCJL.1/ RSV/Luc, which contains the Rous sarcoma virus long terminal repeat, the firefly luciferase cDNA, and the SV40 small-t intron/polyadenylation signal, flanked by Ad5 map units 0.0-1.3 and 9.2-15.8. The resulting virus, designated AdRSVLuc, contains a substitution of the expression cassette bearing the luciferase reporter gene in place of E1 sequences between 1.3 and 9.2 map units (Mazur, W., and B. A. French, unpublished observations). For details regarding the design, assembly, rescue, titration, and propagation of the adenoviral constructs see reference 28 . After $24 \mathrm{~h}$ in culture, the adult ventricular myocytes were incubated for an additional $48 \mathrm{~h}$ with medium alone or medium containing up to $2 \times 10^{8}$ plaque-forming units (PFU) ${ }^{1}$ of AdFG140, AdRSVLuc, or AdHCMVsp1LacZ.

$\beta$-Galactosidase expression. The infection efficiency of AdHCMVsp $1 \mathrm{LacZ}$ in adult ventricular myocytes was determined by histochemical staining for $\beta$-galactosidase activity and was compared with quantitative analysis of $\beta$-galactosidase in the cardiac myocyte extracts, $48 \mathrm{~h}$ after infection with AdHCMVsplLacZ or control virus. As the $\mathrm{pH}$ optima for bacterial and mammalian $\beta$-galactosidases differ substantially (7.0-7.5 and 3-6, respectively), $E$. coli lacZ activity can be assayed in recipient cells in isolation from any contribution by endogenous $\beta$-galactosidases (29). For histochemical analysis, ventricular myocytes were fixed in $0.5 \%$ glutaraldehyde-phosphate buffered saline, $\mathrm{pH} \mathrm{7.2,} \mathrm{for} 5 \mathrm{~min}$ at $37^{\circ} \mathrm{C}$, then were stained with $5 \mathrm{mM} \mathrm{K}_{4} \mathrm{Fe}(\mathrm{CN})_{6}, 5$ $\mathrm{mM} \mathrm{K}_{3} \mathrm{Fe}(\mathrm{CN})_{6}, 2 \mathrm{mM} \mathrm{MgCl} 2,1 \mathrm{mg} / \mathrm{ml}$ 5-bromo-4-chloro-3-indolyl$\beta$-D galactopyranoside (X-gal; Boehringer Mannheim Corp., India-

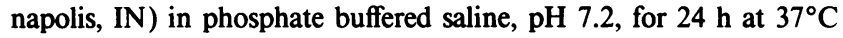
(29). The proportion of cells that expressed $\beta$-galactosidase was calculated for $\sim 70$ rod-shaped ventricular myocytes, at each concentration of virus examined. For colorimetric determination of $\beta$-galactosidase activity, cells were harvested in $150 \mu \mathrm{l}$ of $0.25 \mathrm{M}$ Tris- $\mathrm{HCl}, \mathrm{pH}$ 7.4. Cell lysates $(80 \mu \mathrm{l})$ were incubated with $4.85 \mathrm{mg} / \mathrm{ml}$ chlorophenol red- $\beta$-Dgalactosidase (Boehringer Mannheim), $62.3 \mathrm{mM} \mathrm{Na} 2 \mathrm{HPO}_{4}, 1 \mathrm{mM}$ $\mathrm{MgCl}_{2}, 45 \mathrm{mM} \beta$-mercaptoethanol for $30 \mathrm{~min}$ at $37^{\circ} \mathrm{C}(30) . \beta$-galactosidase activity was measured as absorbance at a wavelength of $575 \mathrm{~nm}$ and was corrected for the protein content of cell lysates, assayed by the method of Bradford (31). Results were compared by Scheffe's multiple comparison test for analysis of variance and the unpaired two-tail $t$ test, using a significance level of $P<0.05$.

Luciferase expression. Luciferase activity was monitored as oxidation of luciferin in the presence of coenzyme A (32). Cells were lysed with $150 \mu \mathrm{l}$ of $25 \mathrm{mM}$ Tris-phosphate, $2 \mathrm{mM}$ DTT, 2 mM EDTA, $10 \%$ glycerol, and $0.1 \%$ Triton X-100. 20- $\mu$ l aliquots of each lysate were mixed with $100 \mu \mathrm{l}$ of $20 \mathrm{mM}$ tricine, $1.07 \mathrm{mM} \mathrm{MgCO}_{3} \cdot 4 \mathrm{Mg}(\mathrm{OH})_{2} \cdot 5$ $\mathrm{H}_{2} \mathrm{O}, 2.67 \mathrm{mM} \mathrm{MgSO}{ }_{4}, 0.1 \mathrm{mM}$ trans-1,2-diaminocyclohexane$N, N, N^{\prime}, N^{\prime}$-tetraacetic acid, $33.3 \mathrm{mM}$ DTT, $270 \mu \mathrm{M}$ coenzyme A (Pharmacia Fine Chemicals, Piscataway, NJ), $470 \mu \mathrm{M}$ D-luciferin (Boehringer Mannheim Corp.), and $530 \mu \mathrm{M}$ ATP. Samples were assayed in duplicate using a luminometer (model 2010; Analytical Luminescence Laboratories, San Diego, CA), and luminescence was corrected for protein content ( $n=4$ plates, for each experimental condition).

\section{Results}

After isolation from adult ventricular myocardium, resuspension in the presence of $1.4 \mathrm{mM} \mathrm{Ca}^{2+}$, and preplating for $2 \mathrm{~h}$ to remove nonadherent rounded cells, $>80 \%$ of the resulting cardiac cells displayed the rod-shaped morphology and sarcomeric cross-striations characteristic of myocardium in situ. In agreement with the outcome of related protocols described by Volz (24) and Lundgren (25), the morphological phenotype after overnight incubation $(67 \pm 2 \%$ rods) was stably maintained for at least $96 \mathrm{~h}(63 \pm 3 \%)$. To overcome the potential limitation that gene transfer into adult cardiac myocytes might occur preferentially or exclusively in the subpopulation of structurally altered, dedifferentiated cells $(33,34)$, ventricular myocytes were infected after $24 \mathrm{~h}$ in culture and were analyzed $48 \mathrm{~h}$ later by histochemical staining for lacZ activity, confining the experiment to early intervals and permitting direct identification of lacZ $\mathrm{Z}^{+}$cells. Adult rat ventricular myocytes that were infected with lacZ-encoding adenovirus at high titer $\left(2 \times 10^{8}\right.$ PFU per $35-\mathrm{mm}$ culture dish) efficiently expressed the exogenous lacZ gene, as indicated by the prevalence of blue chromagen in characteristic rod-shaped cells (Fig. 1. $A-C$ ). To obviate

1. Abbreviation used in this paper: PFU, plaque-forming units. 


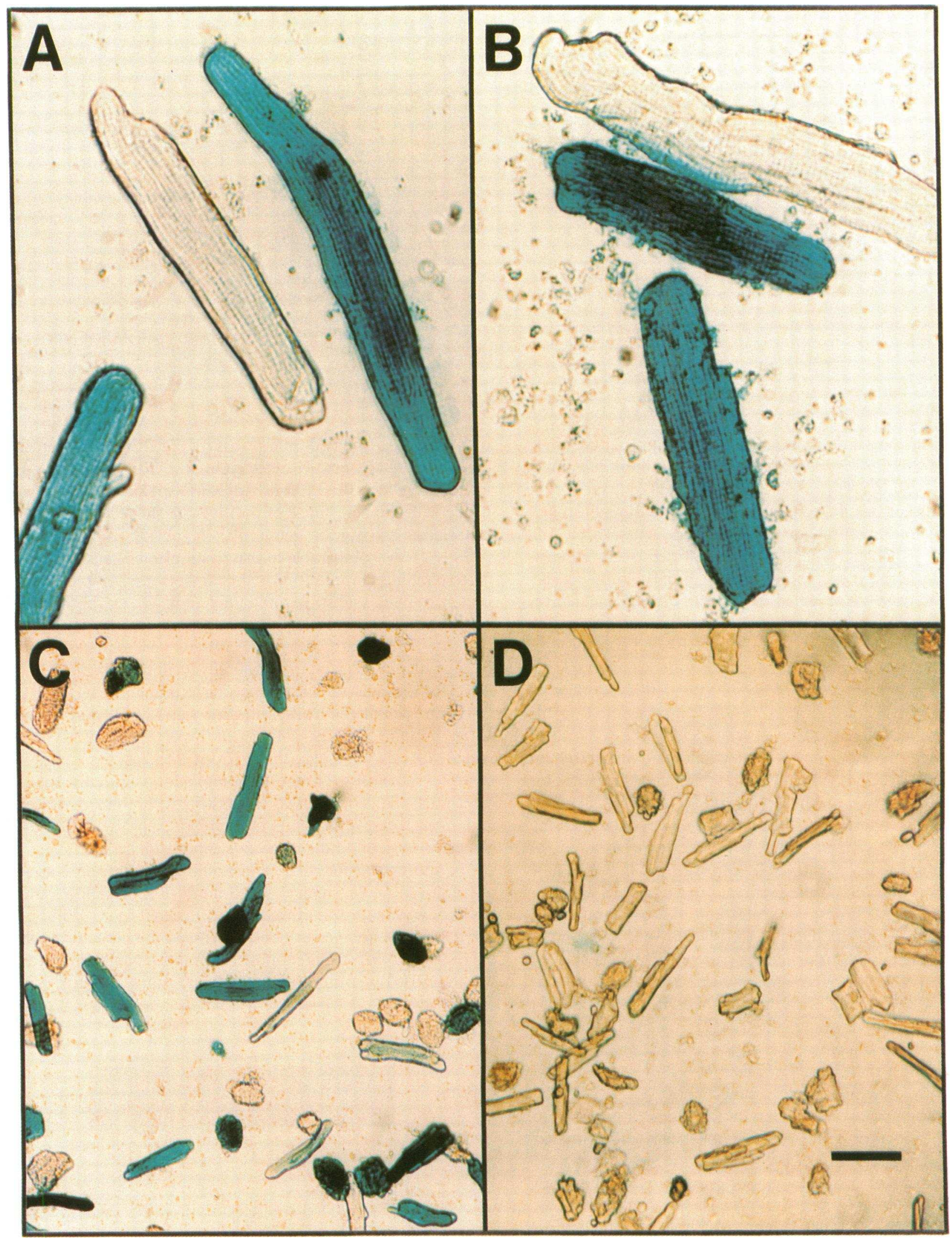

Figure 1. Recombinant type 5 adenovirus mediates efficient gene transfer to adult rat ventricular muscle cells. Representative fields are shown for cells assayed for $E$. coli lacZ activity $48 \mathrm{~h}$ after infection with $2.0 \times 10^{8} \mathrm{PFU}$ of $(A, B, C) \operatorname{AdHCMVsp} 1$ lacZ or $(D)$ the control virus, AdFG140. Bar, $(A, B) 40 \mu \mathrm{m} ;(C, D) 100 \mu \mathrm{m}$. Incubations for the histochemical reaction were $24 \mathrm{~h}$; uninfected and AdFG140-infected ventricular myocytes remained colorless even after incubation for an additional 3 days. 
A

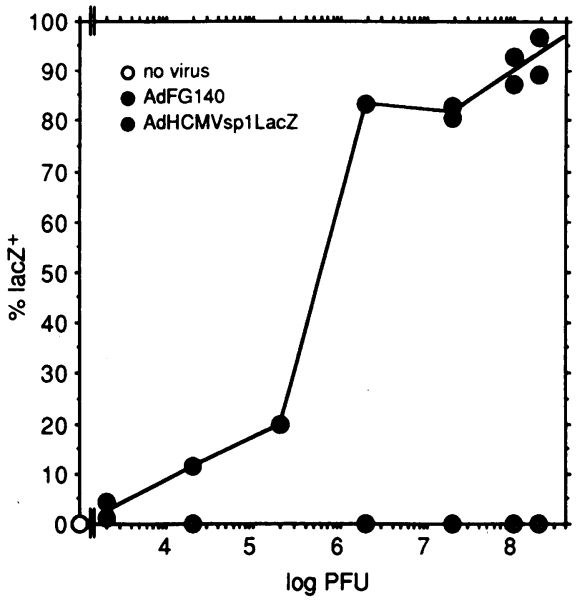

B

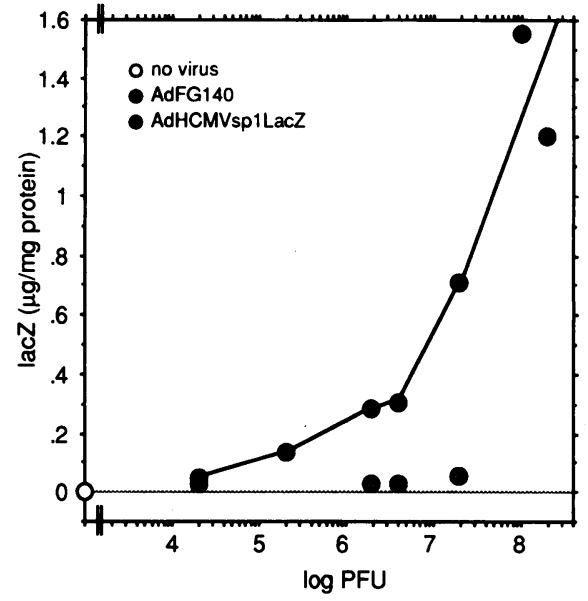

Figure 2. $(A)$ The percentage of lacZ $Z^{+}$ ventricular myocytes and $(B)$ lacZ content (microgram per milligram protein) are shown as a function of viral concentration. Results in $A$ are calculated for the morphologically differentiated, rod-shaped ventricular muscle cells. (Black) AdHCMVsp1LacZ; (grey) AdFG140; (white) no virus. concern that the procedures for cell isolation and culture might induce endogenous $\beta$-galactosidase activity in ventricular myocytes, as suggested for injured canine arteries (35), and to rule out the further possibility that adenovirus itself might induce the endogenous mammalian $\beta$-galactosidase genes, AdFG140infected ventricular myocytes and uninfected cells were analyzed histochemically, at the same stage of cell culture. $\beta$-galactosidase activity was detected exclusively in ventricular myocytes infected with AdHCMVsplLacZ, and was never observed in cardiac myocytes infected with the control virus (Fig. $1 D$ ) or in uninfected ventricular cells. Comparable results were obtained in each of two independent experiments.

To eliminate uncertainties arising from the questionable viability or dedifferentiation of cells lacking the rod-shaped morphology, the efficiency for infection of adult ventricular myocytes by AdHCMVspl LacZ was separately determined for characteristic rod-shaped myocytes and for the total cell population. The proportion of rod-shaped myocytes expressing lacZ increased systematically with the concentration of AdHCMVsp1LacZ $(P=0.0282)$ and was half-maximal at 4 $\times 10^{5}$ PFU (Fig. $2 \mathrm{~A}$ ). Infrequent lacZ-positive cells were observed even at the lowest concentration of virus examined ( 2 $\times 10^{3} \mathrm{PFU}$ ). The percentage of rod-shaped ventricular myocytes that contained histochemically detectable lacZ activity approached $80 \%$ at $2 \times 10^{6}$ and $90 \%$ at $2 \times 10^{8}$ PFU. In contrast, myocytes infected with the lacZ-free virus $(P=0.0005)$ and uninfected myocytes $(P=0.0008)$ remained histochemically negative at all viral titers tested (Fig. $2 A$ ), even with prolongation of the histochemical reaction for $4 \mathrm{~d}$. The efficiency for adenoviral infection noted above for rod-shaped myocytes was comparable to that for the total cell population: given the high proportion of morphologically differentiated ventricular cells resulting from the culture procedures used here, rod-shaped ventricular myocytes comprised more than two-thirds of the lacZ ${ }^{+}$cells produced at each viral titer. Thus, the cells that are amenable to adenoviral infection and expression of the heterologous gene are representative of the adult ventricular myocytes present in the culture.

To ensure that $\beta$-galactosidase activity was strictly contingent on the exogenous lac $Z$ sequences, parallel cultures of adenovirus-infected ventricular myocytes were analyzed more quantitatively, by a colorimetric assay (Fig. 2 B). $\beta$-Galactosidase activity was readily detected at $4 \times 10^{5}$ PFU and was maximal at $5 \times 10^{7} \mathrm{PFU}$ of AdHCMVsp1LacZ, in concordance with the percentage of positive rod-shaped cells. $\beta-\mathrm{Ga}-$ lactosidase activity in ventricular myocytes infected with AdFG140 was comparable to that in uninfected cells: for each corresponding concentration of the control virus, $A_{575}$ was similar to that due to substrate and buffer alone. To establish independent evidence that adenovirus infection of adult ventricular myocytes had occurred, separate cultures were exposed to $10^{8}$ PFU of adenovirus containing a firefly luciferase reporter gene driven by the Rous sarcoma virus long terminal repeat (Fig. 3 ). Luciferase activity $24 \mathrm{~h}$ after infection was $32,651 \pm 5,465$ light $\mathrm{U} / \mu \mathrm{g}$ protein, whereas activity in myocytes infected with AdFG140 was indistinguishable from background luminescence $(P=0.0001)$. Thus, infection of adult ventricular myocytes was validated with two contrasting recombinant viruses and, in each case, production of the reporter protein was altogether contingent on the respective expression cassette.

To address the potential impact of high titer infection itself on adult ventricular myocytes, cell number, morphology, and viability were compared in cultures subjected to $10^{8} \mathrm{PFU}$ of AdHCMVsp1LacZ versus control cells. In concordance with the results of others using serum-free conditions and laminin as substrate (36), cell number at $72 \mathrm{~h}$ in control cultures was

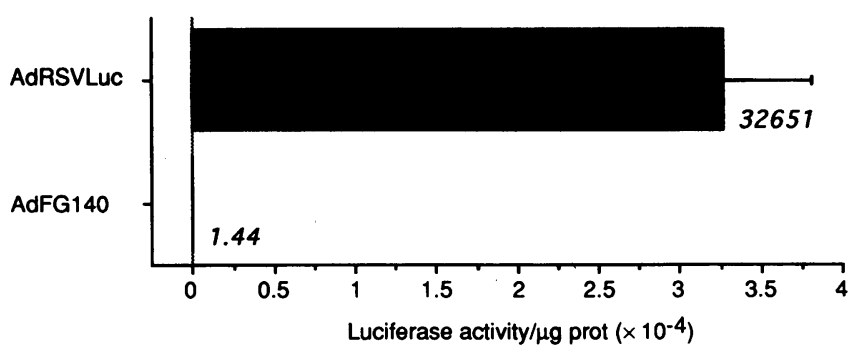

Figure 3. Luciferase activity in adenovirus-infected adult ventricular muscle cells. Cells were assayed $48 \mathrm{~h}$ after infection with $10^{8} \mathrm{PFU}$ of (upper bar) AdRSVLuc or (lower bar) AdFG140. Results $(m e a n \pm S E)$ are expressed as light units per microgram protein. 
A

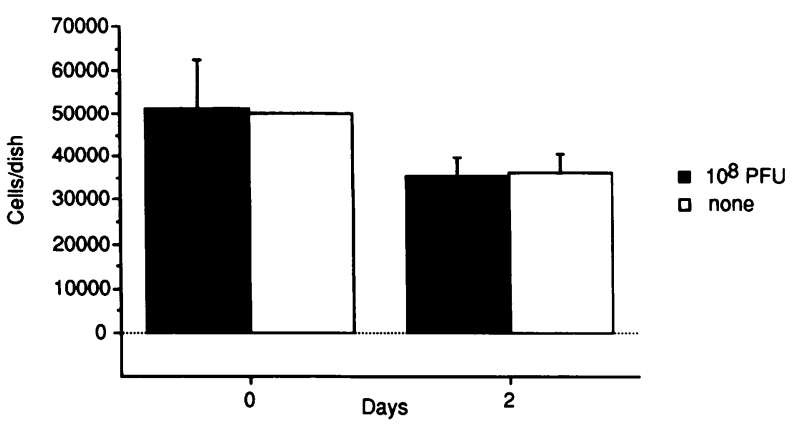

B

C

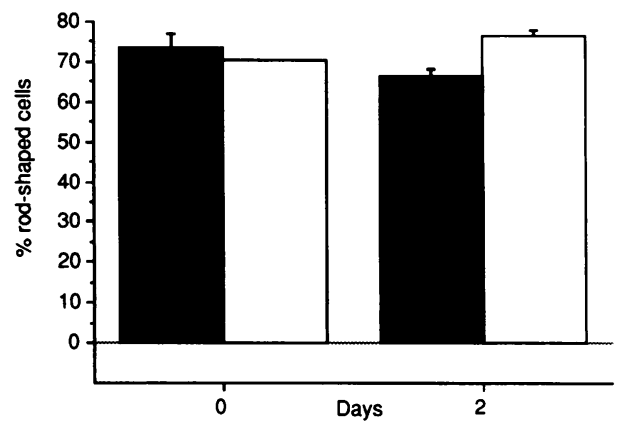

$10^{8} \mathrm{PFU}$

a none

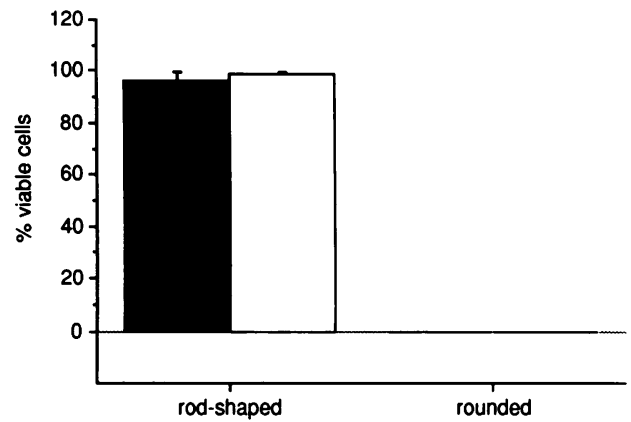

$10^{8} \mathrm{PFU}$

a none

Figure 4. $(A)$ Cell number, $(B)$ morphology, and $(C)$ viability were similar in adenovirus-infected and control adult ventricular muscle cells. Cells were analyzed 24 or $48 \mathrm{~h}$ after infection with $10^{8} \mathrm{PFU}$ of (black) AdHCMVsp1LacZ; (white) no virus. Results for $C$ were obtained after infection for $48 \mathrm{~h}$.

roughly one-third of the initial inoculum of $10^{5}$ cells $(35,458 \pm 4,458)$. No deterioration of cell number occurred in virus-infected cells $(36,141 \pm 4,317$; Fig. $4 A)$. The proportion of adult ventricular myocytes retaining the differentiated, rodshaped morphology was close to $70 \%$ under each of the conditions tested (Fig. $4 \mathrm{~B}$ ). Virtually all rod-shaped myocytes were viable, as determined by trypan blue exclusion $(96.3 \pm 3.2 \%$ for adenovirus-infected cells; $99.3 \pm 0.4 \%$ for control cells; Fig. 4 $C)$. Thus, under the conditions tested, adenovirus infection by itself had no obvious effect on the survival or morphology of adult ventricular muscle cells.

\section{Discussion}

For cardiac muscle as for other classes of cells, the introduction of foreign DNA has become a virtually indispensable tool for investigations of the normal and abnormal phenotype. How- ever, by comparison with other experimental systems, a molecular dissection of the cardiac myocyte has been hampered by obstacles to the genetic manipulation of adult ventricular muscle cells in vitro. To circumvent the expected inefficiency of more conventional approaches, we tested the hypothesis that recombinant adenovirus would provide a means for highly efficient gene transfer to adult ventricular myocytes in culture. Our results establish that morphologically differentiated, rodshaped ventricular muscle cells are competent for uptake of recombinant adenovirus and expression of the heterologous genes. Precautions must be taken in the use of $\beta$-galactosidase as a reporter protein $(35,37)$. In our study, the histochemical and quantitative assays to monitor lac $Z$ activity both discriminate between mammalian and bacterial $\beta$-galactosidases (29), and spurious activity was never seen in uninfected cardiac muscle cells or cells infected with control virus. Moreover, adenoviral infection of adult ventricular myocytes was corroborated independently, using a second recombinant virus encoding firefly luciferase. The efficiency for genetic modification of adult ventricular myocytes approached $90 \%$ at $10^{8}$ PFU, exceeding by 450 -fold the reported success rate for adenoviral gene transfer into mouse myocardium in vivo (38) and approximating the homogeneity obtained in neonatal ventricular cells (39). The fact that all rounded myocytes were nonviable by trypan blue inclusion suggests that lacZ activity in rounded cells, illustrated in Fig. 1, is likely to reflect rounding caused by the prolonged incubation for X-gal staining: this interpretation has been substantiated by an alternative procedure, using brief incubation with the membrane-permeant, fluorogenic substrate $C_{12}$-fluorescein di- $\beta$-D-galactopyranoside ( 40$)$ to image lacZ activity in living ventricular muscle cells (Kirshenbaum, L. A., K. A. Angelides, B. A. French, and M. D. Schneider, unpublished observations).

The procedure for generation of recombinant adenovirus (41) relies on homologous recombination between adenoviral E1 sequences flanking a eukaryotic expression cassette and a modified Ad5 genome that exceeds the packaging limitation for adenoviral capsids. The adenovirus E1A protein regulates numerous viral and cellular genes, at least in part by physical interaction with nuclear proteins including CREB/ATF, Rb, cyclin A, Fos, Jun, and TFIID, the TATA box transcription factor $(42,43)$, and can dissociate transcription factor complexes involving the cellular protein E2F (44). In skeletal muscle, E1A represses differentiation and, more specifically, blocks trans-activation by myogenic helix-loop-helix proteins (45). Thus, an aspect of adenovirus itself which bears importantly on the potential for affecting the cardiac phenotype factitiously is the absence of E1A, E1B, and E3 activity from the strains of virus used here. Conversely, adenovirus-mediated gene transfer would provide an effective means for intentionally modifying ventricular myocytes with one or more of these proteins. Although there was no obvious impact of adenoviral infection here on myocyte survival or morphology, the present study does not exclude effects at longer intervals or higher multiplicities of infection.

Interest in adenovirus-mediated gene transfer has been accentuated by recent demonstrations that replication-deficient adenovirus can stably modify mouse skeletal muscle in vivo (46), efficiently infect endothelium of human umbilical veins (47), and direct the expression of potentially therapeutic proteins in airway epithelium (48). Recognized advantages of ade- 
novirus-based strategies $(48,49)$ include lack of dependence on host cell proliferation, broad target range, limited pathogenicity in humans, capacity for foreign DNA (especially if helper virus is used for propagation), high titer production, and the ability of adenovirus augmented gene transfer by transferrin-polylysine conjugates (49). For fundamental studies of signal transduction and transcriptional control in the heart, the remarkable uniformity for infection and applicability to adult ventricular myocytes shown in the present study establish that replication-deficient adenovirus can complement existing techniques for achieving gene transfer in cardiac muscle.

\section{Acknowledgments}

The authors are grateful to A. Bett and F. Graham for viral constructs and suggestions, T. Borg for laminin and advice, F. Ervin for technical assistance, and $\mathrm{T}$. Brand for his reading of the manuscript.

This work was supported by grants to $M$. D. Schneider from the National Institutes of Health (RO1 HL-39141, RO1 HL-47567, T32 HL-07706) and the American Heart Association (91-009790). L. A. Kirshenbaum and W. R. MacLellan are Fellows of the Medical Research Council of Canada. M. D. Schneider is an Established Investigator of the American Heart Association.

\section{References}

1. Parker, T. G., K.-L. Chow, R. J. Schwartz, and M. D. Schneider. 1990. Differential regulation of skeletal $\alpha$-actin transcription in cardiac muscle by two fibroblast growth factors. Proc. Natl. Acad. Sci. USA. 87:7066-7070.

2. Parker, T. G., K.-L. Chow, R. J. Schwartz, and M. D. Schneider. 1992. Positive and negative control of the skeletal alpha-actin promoter in cardiac muscle: a proximal serum response element is sufficient for induction by basic fibroblast growth factor (FGF) but not for inhibition by acidic FGF. J. Biol. Chem. 267:3343-3350.

3. Tsika, R. W., J. J. Bahl, L. A. Leinwand, and E. Morkin. 1990. Thyroid hormone regulates expression of a transfected human alpha-myosin heavy-chain fusion gene in fetal rat heart cells. Proc. Natl. Acad. Sci. USA. 87:379-383.

4. Navankasattusas, S., H. Zhu, A. V. Garcia, S. M. Evans, and K. R. Chien. 1992. A ubiquitous factor (HF-1a) and a distinct muscle factor (HF-1b/MEF-2) form an E-box-independent pathway for cardiac muscle gene expression. $\mathrm{Mol}$. Cell. Biol. 12:1035-1043.

5. Parmacek, M. S., A. J. Vora, T. L. Shen, E. Barr, F. Jung, and J. M. Leiden. 1992. Identification and characterization of a cardiac-specific transcriptional regulatory element in the slow/cardiac troponin C gene. Mol. Cell. Biol. 12:19671976.

6. Thompson, W. R., B. Nadal-Ginard, and V. Mahdavi. 1991. A MyoD1-independent muscle-specific enhancer controls the expression of the beta-myosin heavy chain gene in skeletal and cardiac muscle cells. J. Biol. Chem. 266:2267822688.

7. Kariya, K., L. R. Karns, and P. C. Simpson. 1991. Expression of a constitutively activated mutant of the beta-isozyme of protein kinase-C in cardiac myocytes stimulates the promoter of the beta-myosin heavy chain isogene. J. Biol. Chem. 266:10023-10026.

8. Kovacic-Milivojevic, B., and D. G. Gardner. 1992. Divergent regulation of the human atrial natriuretic peptide gene by c-jun and c-fos. Mol. Cell. Biol. 12:292-301.

9. Zimmermann, K. A., G. D. Yancopoloulos, R. G. Collum, R. K. Smith, N. E. Kohl, K. A. Denis, M. M. Nau, O. N. Witte, D. Toran-Allerand, C. E. Gee, et al. 1986. Differential expression of myc family genes during murine development. Nature (Lond.). 319:780-783.

10. Springhorn, J. P., O. Ellingsen, H.-J. Berger, R. A. Kelly, and T. W. Smith. 1992. Transcriptional regulation in cardiac muscle: coordinate expression of Id with a neonatal phenotype during development and following a hypertrophic stimulus in vitro. J. Biol. Chem. 267:14360-14365.

11. Mann, D. L., R. L. Kent, B. Parsons, and G. Cooper 4th. 1992. Adrenergic effects on the biology of the adult mammalian cardiocyte. Circulation. 85:790 804.

12. Luetje, C. W., K. M. Tietje, J. L. Christian, and N. M. Nathanson. 1988. Differential tissue expression and developmental regulation of guanine nucleotide binding regulatory proteins and their messenger RNAs in rat heart. J. Biol. Chem. 263:13357-13365.
13. Schneider, M. D., and T. G. Parker. 1991. Cardiac growth factors. Prog. Growth Factor Res. 3:1-26.

14. Nadal-Ginard, B., and V. Mahdavi. 1989. Molecular basis of cardiac performance: plasticity of the myocardium generated through protein isoform switches. J. Clin. Invest. 84:1693-1700.

15. Lin, H., M. S. Parmacek, G. Morle, S. Bolling, and J. Leiden. 1990. Expression of recombinant genes in myocardium in vivo after injection of DNA. Circulation. 82:2217-2221.

16. Kitsis, R. N., P. M. Buttrick, E. M. Mcnally, M. L. Kaplan, and L. A Leinwand. 1991. Hormonal modulation of a gene injected into rat heart in vivo. Proc. Natl. Acad. Sci. USA. 88:4138-4142.

17. Field, L. J. 1988. Atrial natriuretic factor-SV40 $\mathrm{T}$ antigen transgenes produce tumors and cardiac arrhythmias in mice. Science (Wash. DC). 239:10291033

18. Johnson, J. E., B. J. Wold, and S. D. Hauschka. 1989. Muscle creatine kinase sequence elements regulating skeletal and cardiac muscle expression in transgenic mice. Mol. Cell. Biol. 9:3393-3399.

19. Jackson, T., M. F. Allard, C. M. Sreenan, L. K. Doss, S. P. Bishop, and J. L. Swain. 1990. The c-myc proto-oncogene regulates cardiac development in transgenic mice. Mol. Cell. Biol. 10:3709-3716.

20. Rockman, H. A., R. S. Ross, A. N. Harris, K. U. Knowlton, M. E. Steinhelper, L. J. Field, J. Ross, and K. R. Chien. 1991. Segregation of atrial-specific and inducible expression of an atrial natriuretic factor transgene in an in vivo murine model of cardiac hypertrophy. Proc. Natl. Acad. Sci. USA. 88:8277-8281.

21. Kirshenbaum, L. A., T. P. Thomas, A. K. Randhawa, and P. K. Singal. 1992. Time-course of cardiac myocyte injury due to oxidative stress. Mol. Cell. Biochem. 111:25-31.

22. Bihler, I., K. Ho, and P. C. Sawh. 1984. Isolation of calcium-tolerant myocytes from adult rat heart. Can. J. Physiol. Pharmacol. 62:581-588.

23. Parker, T. G., S. E. Packer, and M. D. Schneider. 1990. Peptide growth factors can provoke "fetal" contractile protein gene expression in rat cardiac myocytes. J. Clin. Invest. 85:507-514.

24. Volz, A., H. M. Piper, B. Siegmund, and P. Schwartz. 1991. Longevity of adult ventricular rat heart muscle cells in serum-free primary culture. J. Mol. Cell. Cardiol. 23:161-173

25. Lundgren, E., L. Terracio, S. Mårdh, and T. K. Borg. 1985. Extracellular matrix components influence the survival of adult cardiac myocytes in vitro. Exp. Cell Res. 158:371-381.

26. Graham, F. L. 1984. Covalently closed circles of human adenovirus DNA are infectious. EMBO (Eur. Mol. Biol. Organ.) J. 3:2917-2922.

27. Jones, N., and T. Shenk. 1978. Isolation of deletion and substitution mutants of adenovirus type 5. Cell. 13:181-188.

28. Graham, F. L., and L. Prevec. 1991. Manipulation of adenovirus vectors. In Gene Transfer and Expression Protocols. E. J. Murray, editor. Humana Press Inc., Clifton, NJ. pp. 109-127.

29. MacGregor, G. R., A. E. Mogg, J. F. Burke, and C. T. Caskey. 1987. Histochemical staining of clonal mammalian cell lines expressing $E$. coli $\beta$ galactosidase indicates heterogeneous expression of the bacterial gene. Somatic Cell Mol. Genet. 13:253-265.

30. Eustice, D. C., P. A. Feldman, P. A. M. Colberg, R. M. Buckery, and R. H. Neubauer. 1991. A sensitive method for the detection of beta-galactosidase in transfected mammalian cells. Biotechniques. 11:739-740.

31. Bradford, M. A. 1976. A rapid and sensitive method for the quantitation of microgram quantities of protein utilizing the principle of protein-dye binding. Anal. Biochem. 72:248-254.

32. Wood, K. V. 1991. The origin of beetle luciferase. In Bioluminescence and Chemiluminescence. P. Stanley, and L. Kricka, editors. J. Wiley \& Sons, Ltd., Chichester, UK. pp. 11.

33. Claycomb, W. C., and R. L. Moses. 1988. Growth factors and TPA stimulate DNA synthesis and alter the morphology of cultured terminally differentiated adult rat cardiac muscle cells. Dev. Biol. 127:257-265.

34. Eppenberger-Eberhard, T. M., I. Flamme, V. Kurer, and H. M. Eppenberger. 1990. Re-expression of alpha-smooth muscle actin isoform in cultured adult rat cardiomyocytes. Dev. Biol. 139:269-278.

35. Lim, C. S., G. D. Chapman, R. S. Gammon, J. B. Muhlestein, R. P. Bauman, R. S. Stack, and J. L. Swain. 1991. Direct in vivo gene transfer into the coronary and peripheral vasculatures of the intact dog. Circulation. 83:20072011.

36. Piper, H. M., S. L. Jacobson, and P. Schwartz. 1988. Determinants of cardiomyocyte development in long-term primary culture. J. Mol. Cell. Cardiol. 20:825-835.

37. Shimohama, S., M. R. Rosenberg, A. M. Fagan, J. A. Wolff, M. P. Short, X. O. Breakfield, T. Friedmann, and F. H. Gage. 1989. Grafting genetically modified cells into the rat brain: characteristics of $E$. coli $\beta$-galactosidase as a reporter gene. Mol. Brain Res. 5:271-278.

38. Stratford-Perricaudet, L. D., I. Makeh, M. Perricaudet, and P. Briand. 
1992. Widespread long-term gene transfer to mouse skeletal muscles and heart. $J$. Clin. Invest. 90:626-630.

39. Sen, D., P. Dunnmon, S. Henderson, R. D. Gerard, and K. R. Chien 1988. Terminally differentiated neonatal rat myocardial cells proliferate and maintain specific differentiated functions following expression of SV40 large T antigen. J. Biol. Chem. 263:19132-19136.

40. Zhang, Y. Z., J. J. Naleway, K. D. Larison, Z. J. Huang, and R. P. Haugland. 1991. Detecting lacZ gene expression in living cells with new lipophilic fluorogenic beta-galactosidase substrates. FASEB (Fed. Am. Soc. Exp. Biol.) J. 5:3108-3113.

41. McGrory, W. J., D. S. Bautista, and F. L. Graham. 1988. A simple technique for the rescue of early region 1 mutations into infectious human adenovirus type 5. Virology. 163:614-617.

42. Horikoshi, N., K. Maguire, A. Kralli, E. Maldonado, D. Reinberg, and R. Weinmann. 1991. Direct interaction between adenovirus-E1A protein and the TATA box binding transcription factor-IID. Proc. Natl. Acad. Sci. USA. 88:5124-5128.

43. Shenk, T., and J. Flint. 1991. Transcriptional and transforming activities of the adenovirus E1A proteins. Adv. Cancer Res. 57:47-85.

44. Raychaudhuri, P., S. Bagchi, S. H. Devoto, V. B. Kraus, E. Moran, and J. R. Nevins. 1991. Domains of the adenovirus E1A protein required for onco- genic activity are also required for dissociation of E2F transcription factor complexes. Genes \& Dev. 5:1200-1211.

45. Braun, T., E. Bober, and H. H. Arnold. 1992. Inhibition of muscle differentiation by the adenovirus $E$ la protein: repression of the transcriptional activating function of the HLH protein Myf-5. Genes \& Dev. 6:888-902.

46. Quantin, B., L. D. Perricaudet, S. Tajbakhsh, and J. L. Mandel. 1992. Adenovirus as an expression vector in muscle cells in vivo. Proc. Natl. Acad. Sci. USA. 89:2581-2584.

47. Lemarchand, P., H. A. Jaffe, C. Danel, M. C. Cid, H. K. Kleinman, L. Stratford-Perricaudet, M. Perricaudet, A. Pavirani, J. P. Lecocq, and R. G. Crystal. 1992. Adenovirus-mediated transfer of a recombinant human alpha 1-antitrypsin cDNA to human endothelial cells. Proc. Natl. Acad. Sci. USA. 89:64826486.

48. Rosenfeld, M. A., K. Yoshimura, B. C. Trapnell, K. Yoneyama, E. R. Rosenthal, W. Dalemans, M. Fukayama, J. Bargon, L. E. Stier, L. Stratford-Perricaudet, M. Perricaudet, et al. 1992. In vivo transfer of the human cystic fibrosis transmembrane conductance regulator gene to the airway epithelium. Cell. 68:143-155.

49. Curiel, D. T., S. Agarwal, E. Wagner, and M. Cotten. 1991. Adenovirus enhancement of transferrin-polylysine-mediated gene delivery. Proc. Natl. Acad. Sci. USA. 88:8850-8854. 